\title{
Burkholderia ginsengisoli sp. nov., a $\beta$-glucosidase-producing bacterium isolated from soil of a ginseng field
}

\author{
Ho-Bin Kim, ${ }^{1}$ Min-Ju Park, ${ }^{1}$ Hee-Chan Yang, ${ }^{1}$ Dong-Shan An, ${ }^{2}$ \\ Hai-Zhu $\mathrm{Jin}^{3}$ and Deok-Chun Yang ${ }^{1}$ \\ ${ }^{1}$ Department of Oriental Medicinal Material and Processing, College of Life Science, Kyung \\ Hee University, 1 Seocheon-dong, Giheung-gu, Yongin-si, Gyeonggi-do 446-701, South Korea \\ ${ }^{2}$ Department of Biological Sciences, Korea Advanced Institute of Science and Technology, \\ 373-1 Guseong-dong, Yuseong-gu, Daejeon 305-701, South Korea \\ ${ }^{3}$ Institute of Food Science and Engineering, Yantai University, Yantai 264005, People's \\ Republic of China
}

Correspondence

Deok-Chun Yang

dcyang@khu.ac.kr

\begin{abstract}
A bacterial strain (designated $\mathrm{KMYO}^{\top}$ ) that possesses $\beta$-glucosidase activity was isolated from soil from a ginseng field in South Korea and was characterized in order to determine its taxonomic position. The bacterium was found to comprise Gram-negative, rod-shaped, motile cells with unipolar polytrichous flagella. On the basis of $16 \mathrm{~S}$ rRNA gene sequence similarity, strain $\mathrm{KMY} 3^{\top}$ was shown to belong to the family Burkholderiaceae of the Betaproteobacteria, being most closely related to Burkholderia caledonica LMG $19076^{\top}$ (97.8\%), Burkholderia terricola LMG $20594^{\top}$ (97.5\%), Burkholderia xenovorans LMG $21463^{\top}(97 \cdot 4 \%)$ and Burkholderia phytofirmans LMG $22146^{\top}(97 \cdot 3 \%)$. Chemotaxonomic data (major ubiquinone, Q-8; major fatty acids, $\mathrm{C}_{17 \text { : o cyclo, }}$ $\mathrm{C}_{16: 0}, \mathrm{C}_{19: 0}$ cyclo $\omega 8 \mathrm{c}$ and summed feature 2 ) supported the affiliation of the novel strain with the genus Burkholderia. The results of DNA-DNA hybridizations and physiological and biochemical tests allowed the strain to be differentiated genotypically and phenotypically from Burkholderia species with validly published names. On the basis of these data, strain $\mathrm{KMY} 03^{\mathrm{T}}$ represents a novel species of the genus Burkholderia, for which the name Burkholderia ginsengisolisp. nov. is proposed. The type strain is $\mathrm{KMYO3}^{\top}\left(=\operatorname{KCTC} 12389^{\top}=\mathrm{NBRC}_{100965^{\top}}\right)$.
\end{abstract}

During a study of bacterial populations (from diverse environmental soils near Daejeon in South Korea) that metabolize ginsenoside Rb1 to Rg3, Rh2 or compound $\mathrm{K}$, a large number of novel $\beta$-glucosidase-producing bacterial strains were isolated (An et al., 2005). In this study, one of these isolates, designated strain $\mathrm{KMY} 3^{\mathrm{T}}$, was subjected to phenotypic, genotypic and chemotaxonomic investigations in order to determine its taxonomic position. The results provide evidence that strain $\mathrm{KMY}^{\mathrm{T}}{ }^{\mathrm{T}}$ represents a novel species within the genus Burkholderia. This genus was first described by Yabuuchi et al. (1992) and currently contains 39 species, which have been isolated from diverse ecological niches ranging from contaminated soils to the respiratory tracts of humans (Coenye \& Vandamme, 2003).

Strain $\mathrm{KMY}^{\mathrm{T}}{ }^{\mathrm{T}}$ was isolated, via direct plating onto R2A agar (Difco), from soil from a ginseng field near Daejeon in

The GenBank/EMBL/DDBJ accession number for the 16S rRNA gene sequence of strain $\mathrm{KMYO3}^{\top}$ is $\mathrm{AB} 201286$.

A negatively stained transmission electron micrograph of strain $\mathrm{KMYOS}^{\top}$ is available as a supplementary figure in IJSEM Online.
South Korea. The resulting colonies were purified by transferring them onto new plates and subjecting them to an additional incubation for 3 days at $30^{\circ} \mathrm{C}$. Purified colonies were tentatively identified from partial $16 \mathrm{~S}$ rRNA gene sequences.

The Gram reaction was performed by using the non-staining method described by Buck (1982). Cell morphology was examined by using light microscopy (Nikon) and transmission electron microscopy (Carl Zeiss) after negative staining with $1 \%(\mathrm{w} / \mathrm{v})$ phosphotungstic acid. Catalase and oxidase tests were performed by using the procedures outlined by Cappuccino \& Sherman (2002). Utilization of substrates as sole carbon sources and several other physiological characteristics were determined with the API 32GN, API 20NE and API ZYM galleries according to the instructions of the manufacturer (bioMérieux). Tests for anaerobic growth were performed in a serum bottle containing R2A broth supplemented with thioglycolate $\left(1 \mathrm{~g} \mathrm{l}^{-1}\right)$ and in which the upper air layer was substituted with nitrogen gas. Tests for the reduction of nitrate and nitrite were performed in serum bottles containing R2A broth supplemented with $\mathrm{KNO}_{3}$ 
$(10 \mathrm{mM})$ and $\mathrm{NaNO}_{2}(10 \mathrm{mM})$, respectively; reduction was monitored on an ion chromatograph (model 790 personal IC; Metrohm) equipped with a conductivity detector and an anion exchange column (Metrosep Anion Supp 4; Metrohm). Nitrogen-fixing ability was determined from growth in $50 \mathrm{ml}$ nitrogen-free medium (DSMZ medium no. 3) contained in a $500 \mathrm{ml}$ Erlenmeyer flask. Acetylene reduction was examined for all liquid cultures by injecting purified acetylene into appropriate containers closed with rubber stoppers to yield $15 \%$ acetylene $(\mathrm{v} / \mathrm{v})$; this was followed by incubation for up to $24 \mathrm{~h}$. Ethylene was measured using a Hewlett Packard 5890A gas chromatograph equipped with a flame-ionization detector and a prepacked column (HayeSep N; Supelco). The primer system PolF-PolR (Poly et al., 2001) was used to amplify a nifH gene, according to the methods described by Im et al. (2004). Degradation of DNA [using DNA agar (Difco) supplemented with $0 \cdot 01 \%$ toluidine blue (Merck)], chitin, CM-cellulose, starch (Atlas, 1993), lipid (Kouker \& Jaeger, 1987) and xylan (Ten et al., 2004) was also investigated; reactions were read after 5 days. Growth at different temperatures and $\mathrm{pH}$ values was assessed after 5 days incubation. Salt tolerance was tested on R2A medium supplemented with $1-10 \%(\mathrm{w} / \mathrm{v}) \mathrm{NaCl}$ after 5 days incubation. Antibiotic-sensitivity tests were performed using filter-paper discs containing the following: streptomycin $\left(5,10\right.$ and $\left.15 \mu \mathrm{g} \mathrm{ml}^{-1}\right)$, tetracycline $(5,10$ and $\left.15 \mu \mathrm{g} \mathrm{ml}^{-1}\right)$, kanamycin $\left(1 \cdot 0,1 \cdot 5\right.$ and $\left.2 \cdot 0 \mathrm{mg} \mathrm{ml}^{-1}\right)$ and ampicillin (20,30 and $50 \mu \mathrm{g} \mathrm{ml}^{-1}$ ) (Sigma). Discs were placed on R2A plates spread with culture of strain $\mathrm{KMY}^{\mathrm{T}} 3^{\mathrm{T}}$ and were then incubated at $30^{\circ} \mathrm{C}$ for 5 days. All of the phenotypic tests described above were performed in duplicate.

Genomic DNA was extracted using a commercial kit (Solgent), and PCR-mediated amplification of the $16 \mathrm{~S}$ rRNA gene and sequencing of the purified PCR product were carried out according to the methods described by Kim et al. (2005). Full sequences of the $16 \mathrm{~S}$ rRNA gene were compiled using SeqMan software (DNASTAR). The $16 \mathrm{~S}$ rRNA gene sequences of related taxa were obtained from the GenBank database. Multiple alignments were performed by using the CLUSTAL_X program (Thompson et al., 1997) and gaps were edited with the BioEdit program (Hall, 1999). Evolutionary distances were calculated using the Kimura two-parameter model (Kimura, 1983). Phylogenetic trees were constructed by using a neighbour-joining method (Saitou \& Nei, 1987) and with the maximum-parsimony method (Fitch, 1971) using MEGA 3 (Kumar et al., 2004) and with bootstrap values based on 1000 replications (Felsenstein, 1985).

Quinones were extracted from cells grown on nutrient broth (Difco) and then analysed as described by Komagata \& Suzuki (1987) by using reversed-phase HPLC. Cellular fatty acids were saponified, methylated and extracted according to the protocol of the Sherlock Microbial Identification System (MIDI). The fatty acids analysed by GC (Hewlett
Packard 6890) were identified using the Microbial Identification software package (Sasser, 1990).

Total DNA for determination of the $\mathrm{G}+\mathrm{C}$ content was extracted from cells grown on a nutrient agar plate (Difco), using the method described by Ausubel et al. (1995). RNA in the DNA solution was removed by incubation with a mixture of RNase A and RNase T1 (20 $\mathrm{U} \mathrm{ml}^{-1}$ in each case) at $30^{\circ} \mathrm{C}$ for $1 \mathrm{~h}$. The $\mathrm{G}+\mathrm{C}$ content of the total DNA was analysed as described by Mesbah et al. (1989), using reversed-phase HPLC. DNA-DNA reassociation was performed fluorometrically at $50{ }^{\circ} \mathrm{C}$ according to the method of Ezaki et al. (1989), using photobiotin-labelled DNA probes and microdilution wells. The prehybridization solution and the hybridization solution contained $2 \times$ SSC $(1 \times$ SSC is $0 \cdot 15 \mathrm{M} \mathrm{NaCl}$ plus $0.015 \mathrm{M}$ sodium citrate), Denhardt's solution and $50 \%$ formamide.

The cells of strain $\mathrm{KMY}^{\mathrm{T}}{ }^{\mathrm{T}}$ were found to be Gram-negative, rod-shaped and motile by means of unipolar polytrichous flagella (see Supplementary Fig. S1 available in IJSEM Online). Colonies grown on R2A were circular, convex and cream-coloured. The temperature range for growth was $25-42^{\circ} \mathrm{C}$; no growth occurred at $45^{\circ} \mathrm{C}$. An internal region of the nifH gene (about $360 \mathrm{bp}$ ) was clearly amplified, and strain $\mathrm{KMY03}^{\mathrm{T}}$ was able to grow well in a nitrogen-free liquid medium. The physiological characteristics of strain KMY $03^{\mathrm{T}}$ are summarized in the species description; Table 1 presents a comparison between selected characteristics of strain $\mathrm{KMYO3}^{\mathrm{T}}$ and the most closely related type strains of the genus Burkholderia.

An almost-complete 16S rRNA gene sequence of strain $\mathrm{KMY}^{\mathrm{T}}$ was obtained $(1462 \mathrm{bp})$. Preliminary sequence comparisons with 16S rRNA gene sequences deposited in the GenBank database indicated that our isolate belonged to the family Burkholderiaceae of the Betaproteobacteria. On the basis of $16 \mathrm{~S}$ rRNA gene sequence similarity, the closest cultured relatives were Burkholderia caledonica LMG $19076^{\mathrm{T}}$ (97.8\%), Burkholderia terricola LMG $20594^{\mathrm{T}}(97 \cdot 5 \%)$, Burkholderia xenovorans LMG $21463^{\mathrm{T}}(97 \cdot 4 \%)$ and Burkholderia phytofirmans LMG $22146^{\mathrm{T}} \quad(97 \cdot 3 \%)$. Relationships between strain $\mathrm{KMY}^{\mathrm{T}} 3^{\mathrm{T}}$ and other members of the genus Burkholderia were also evident in the phylogenetic tree (Fig. 1). Lower levels of sequence similarity $(<97 \cdot 0 \%)$ were found with respect to all other recognized species of the genus Burkholderia.

Ubiquinone Q-8 was found to be the predominant quinone system in this strain; this is similar to the situation in other species of the genus Burkholderia. The cellular fatty acids of strain $\mathrm{KMYO3}^{\mathrm{T}}$ included $\mathrm{C}_{17: 0}$ cyclo $(24 \cdot 9 \%), \mathrm{C}_{16: 0}$ $(16 \cdot 1 \%), \mathrm{C}_{19: 0}$ cyclo $\omega 8 c(15 \cdot 1 \%)$ and summed feature $2\left(\mathrm{C}_{14: 0} 3-\mathrm{OH}\right.$ and/or iso- $\left.\mathrm{C}_{16: 1} \mathrm{I}, 11 \cdot 7 \%\right)$. Significant differences in fatty acid profiles were observed between strain $\mathrm{KMY}^{\mathrm{T}}{ }^{\mathrm{T}}$ and the other type strains of Burkholderia species, e.g. the production of a large amount of the fatty acid $\mathrm{C}_{17: 0}$ cyclo (Table 2). The DNA G+C content of strain $\mathrm{KMY}^{\mathrm{T}}{ }^{\mathrm{T}}$ was $61.6 \mathrm{~mol} \%$, which is quite 


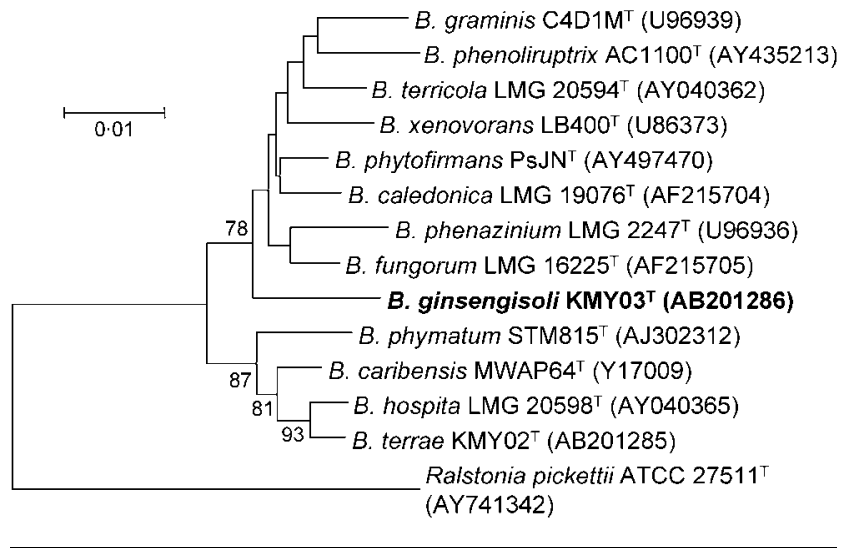

Fig. 1. Neighbour-joining tree, based on 16S rRNA gene sequences, showing the phylogenetic positions of $\mathrm{KMYO}^{\top}$ and related taxa. Bootstrap values (expressed as percentages of 1000 replications) greater than $70 \%$ are shown at branch points. Bar, 0.01 substitutions per nucleotide position.

similar to the values for members of the genus Burkholderia (Table 1).

The values for DNA-DNA relatedness between strain $\mathrm{KMY} 3^{\mathrm{T}}$ and species of the genus Burkholderia were in the range $21-45 \%$ (45\% for B. caledonica LMG $19076^{\mathrm{T}}$, $42 \%$ for B. terricola LMG $20594^{\mathrm{T}}, 35 \%$ for B. xenovorans LMG $21463^{\mathrm{T}}$ and $21 \%$ for B. phytofirmans LMG $22146^{\mathrm{T}}$ ), which are low enough to permit the assignment of strain $\mathrm{KMY}^{\mathrm{T}} 3^{\mathrm{T}}$ to a novel species of the genus Burkholderia.

On the basis of morphological, physiological and chemotaxonomic characteristics, together with data from $16 \mathrm{~S}$ rRNA gene sequence comparisons, strain $\mathrm{KMY} 3^{\mathrm{T}}$ represents a novel member of the genus Burkholderia, for which the name Burkholderia ginsengisoli sp. nov. is proposed.

\section{Description of Burkholderia ginsengisoli sp. nov.}

Burkholderia ginsengisoli (gin.sen.gi.so'li. N.L. n. ginsengum ginseng; L. n. solum soil; N.L. gen. n. ginsengisoli of soil of a ginseng field, the source of the organism).

Cells are Gram-negative rods, $1 \cdot 5-2 \cdot 0 \mu \mathrm{m}$ long by $0 \cdot 3-0.6 \mu \mathrm{m}$ wide, and motile by means of unipolar polytrichous flagella. Colonies grown on R2A are circular, convex and cream-coloured. Temperature range for growth is $25-42{ }^{\circ} \mathrm{C}$; no growth occurs at $45^{\circ} \mathrm{C}$. Optimal growth temperature is $25-30^{\circ} \mathrm{C}$. Growth occurs in the absence of $\mathrm{NaCl}$ and in the presence of $1.5 \%(\mathrm{w} / \mathrm{v}) \mathrm{NaCl}$, but not at $\mathrm{NaCl}$ concentrations above $3.0 \%(\mathrm{w} / \mathrm{v})$. Nitrate is not reduced. Catalase, arginine dihydrolase, urease, $\beta$-galactosidase and $\beta$-glucosidase activities are present. Oxidase and tryptophanase activities are absent. The type strain is positive for the assimilation of adipate, L-malate, phenylacetate, salicin, L-fucose, D-sorbitol, propionate, histidine, 2ketogluconate, L-proline, rhamnose, inositol, DL-lactate,
Table 1. Differential phenotypic characteristics of strain $\mathrm{KMYO3}^{\top}$ and the type strains of phylogenetically related Burkholderia species

Strains: 1, KMY03 ${ }^{\mathrm{T}}$; 2, B. caledonica LMG $19076^{\mathrm{T}}$; 3, B. terricola LMG $20594^{\mathrm{T}}$; 4, B. xenovorans LMG $21463^{\mathrm{T}}$; 5, B. phytofirmans LMG 22146 $;$ 6, Burkholderia fungorum LMG $16225^{\mathrm{T}} ; 7$, Burkholderia phenazinium DSM $10684^{\mathrm{T}} ; 8$, Burkholderia phenoliruptrix LMG $22037^{\mathrm{T}}$. Data for reference species were taken from Coenye et al. (2001, 2004), Goris et al. (2002, 2004) and Sessitsch et al. (2005). The following features are present in all strains investigated: motility, growth at $30^{\circ} \mathrm{C}$ and assimilation of $\mathrm{N}$ acetyl-D-glucosamine, D-glucose, D-gluconate, L-malate, mannitol, mannose and phenylacetate. The following features are absent in all strains investigated: assimilation of mannosidase and $\alpha$-fucosidase. + , Positive; - , negative; ND, no data available.

\begin{tabular}{|c|c|c|c|c|c|c|c|c|}
\hline Characteristic & 1 & 2 & 3 & 4 & 5 & 6 & 7 & 8 \\
\hline Oxidase & - & - & - & + & + & + & + & + \\
\hline Growth at $42^{\circ} \mathrm{C}$ & + & - & - & - & - & - & - & - \\
\hline $\begin{array}{l}\text { Growth in O-F medium } \\
\text { with D-glucose }\end{array}$ & - & + & + & + & + & + & - & + \\
\hline Nitrate reduction & - & - & + & - & - & + & - & - \\
\hline Growth in $1.5 \% \mathrm{NaCl}$ & + & + & - & - & + & + & - & ND \\
\hline $\begin{array}{l}\text { Hydrolysis of arginine, } \\
\text { aesculin and urea }\end{array}$ & + & - & - & - & - & - & - & - \\
\hline \multicolumn{9}{|l|}{ Assimilation of: } \\
\hline Adipate & + & - & - & + & ND & + & - & + \\
\hline Caprate & - & - & - & + & ND & + & - & - \\
\hline Citrate & - & - & - & + & ND & + & - & + \\
\hline Sucrose & - & - & + & - & ND & - & + & ND \\
\hline \multicolumn{9}{|l|}{ Activity of: } \\
\hline Esterase (C4) & - & - & + & + & + & + & + & ND \\
\hline Cysteine arylamidase & - & - & - & + & ND & + & - & ND \\
\hline$\beta$-Galactosidase & + & - & + & - & - & - & - & + \\
\hline$\beta$-Glucuronidase & + & - & - & - & ND & - & - & ND \\
\hline$\beta$-Glucosidase & + & - & - & - & $\mathrm{ND}$ & - & - & ND \\
\hline
\end{tabular}

L-alanine and L-serine and negative for the assimilation of caprate, citrate, D-melibiose, valerate, 3-hydroxybutyrate, 3hydroxybenzoate, 4-hydroxybenzoate, D-ribose, sucrose, itaconate, suberate, acetate, 5-ketogluconate and glycogen. Alkaline phosphatase, esterase lipase (C8), leucine arylamidase, acid phosphatase, naphthol-AS-BI-phosphohydrolase and $\beta$-glucuronidase activities are present; esterase (C4), lipase (C14), valine arylamidase, cystine arylamidase, trypsin, $\alpha$-chymotrypsin, $\alpha$-galactosidase, $\alpha$-glucosidase, $N$-acetyl- $\beta$-glucosaminidase, $\alpha$-mannosidase and $\alpha$-fucosidase are not detected. Resistant to $\left(\mathrm{ml}^{-1}\right)$ ampicillin $(20 \mu \mathrm{g})$ and tetracycline $(5 \mu \mathrm{g})$ and sensitive to kanamycin $(1 \mathrm{mg})$ and streptomycin $(5 \mu \mathrm{g})$. Predominant ubiquinone is Q-8. The major fatty acids are $\mathrm{C}_{17: 0}$ cyclo, $\mathrm{C}_{16: 0}, \mathrm{C}_{19: 0}$ cyclo $\omega 8 \mathrm{c}$ and summed feature 2 . The $\mathrm{G}+\mathrm{C}$ content of the genomic DNA is $61 \cdot 6 \mathrm{~mol} \%$.

The type strain, $\mathrm{KMY}^{\mathrm{T}}{ }^{\mathrm{T}} \quad\left(=\mathrm{KCTC} \quad 12389^{\mathrm{T}}=\mathrm{NBRC}\right.$ $100965^{\mathrm{T}}$ ), was isolated from soil from a ginseng field near Daejeon in South Korea. 
Table 2. Cellular fatty acid composition (\%) of strain $\mathrm{KMYO}^{\top}$ and phylogenetically related Burholderia species

Taxa: 1 , KMY03 ${ }^{\mathrm{T}} ; 2$, B. caledonica $(n=7) ; 3$, B. terricola $(n=17) ; 4$, B. xenovorans $(n=1) ; 5$, B. phytofirmans $(n=1) ; 6$, B. fungorum $(n=9)$; 7, B. phenazinium $(n=2) ; 8, B$. phenoliruptrix $(n=1)$. Data for reference species were taken from Coenye et al. (2001, 2004) (B. caledonica, B. fungorum, B. phenazinium and B. phenoliruptrix), Goris et al. (2002, 2004) (B. terricola and B. xenovorans) and Sessitsch et al. (2005) (B. phytofirmans). Type strains were included for all species. The values shown are mean percentages of total fatty acids ( \pm SD, as appropriate). Fatty acids for which the mean amount in all taxa was less than $1 \%$ are not given;,$-<1 \%$.

\begin{tabular}{|c|c|c|c|c|c|c|c|c|}
\hline Fatty acid & 1 & 2 & 3 & 4 & 5 & 6 & 7 & 8 \\
\hline $\mathrm{C}_{14: 0}$ & $5 \cdot 9$ & $4 \cdot 7 \pm 0 \cdot 2$ & $4 \cdot 8 \pm 0 \cdot 8$ & $4 \cdot 7$ & $3 \cdot 6$ & $4 \cdot 6 \pm 0 \cdot 1$ & $5 \cdot 1 \pm 0 \cdot 5$ & $4 \cdot 0$ \\
\hline $\mathrm{C}_{16: 0}$ & $16 \cdot 1$ & $13 \cdot 6 \pm 1 \cdot 6$ & $14 \cdot 3 \pm 1 \cdot 3$ & $18 \cdot 2$ & $13 \cdot 8$ & $14 \cdot 7 \pm 0 \cdot 9$ & $15 \cdot 7 \pm 2 \cdot 7$ & $19 \cdot 7$ \\
\hline $\mathrm{C}_{18: 1} \omega 7 c$ & $4 \cdot 2$ & $34 \cdot 2 \pm 1 \cdot 7$ & $27 \cdot 8 \pm 8 \cdot 8$ & $27 \cdot 3$ & $44 \cdot 3$ & $35 \cdot 6 \pm 2 \cdot 1$ & $30 \cdot 1 \pm 0 \cdot 1$ & $38 \cdot 3$ \\
\hline $\mathrm{C}_{16: 0} 2-\mathrm{OH}$ & $5 \cdot 6$ & $2 \cdot 4 \pm 0 \cdot 4$ & $3 \cdot 5 \pm 1 \cdot 4$ & $2 \cdot 2$ & $2 \cdot 1$ & $3 \cdot 6 \pm 0 \cdot 5$ & $2 \cdot 0 \pm 1 \cdot 0$ & $1 \cdot 8$ \\
\hline $\mathrm{C}_{16: 1} 2-\mathrm{OH}$ & $2 \cdot 9$ & $2 \cdot 7 \pm 0 \cdot 4$ & $3 \cdot 1 \pm 1 \cdot 2$ & $2 \cdot 2$ & $2 \cdot 3$ & $3 \cdot 5 \pm 0 \cdot 7$ & $3 \cdot 0 \pm 1 \cdot 8$ & $1 \cdot 6$ \\
\hline $\mathrm{C}_{16: 0} 3-\mathrm{OH}$ & $8 \cdot 9$ & $6 \cdot 0 \pm 0 \cdot 4$ & $6 \cdot 6 \pm 1 \cdot 5$ & $7 \cdot 1$ & $4 \cdot 1$ & $5 \cdot 6 \pm 0 \cdot 5$ & $4 \cdot 2 \pm 2 \cdot 0$ & $4 \cdot 7$ \\
\hline $\mathrm{C}_{18: 1} 2-\mathrm{OH}$ & $1 \cdot 2$ & $1 \cdot 1 \pm 0 \cdot 3$ & $1 \cdot 5 \pm 0 \cdot 7$ & - & $1 \cdot 4$ & $1 \cdot 7 \pm 0 \cdot 2$ & $1 \cdot 6 \pm 1 \cdot 0$ & - \\
\hline $\mathrm{C}_{17: 0}$ cyclo & $24 \cdot 9$ & $8 \cdot 4 \pm 1 \cdot 5$ & $14 \cdot 0 \pm 5 \cdot 2$ & $5 \cdot 1$ & $2 \cdot 1$ & $5 \cdot 1 \pm 1 \cdot 6$ & $8 \cdot 4 \pm 0 \cdot 5$ & $1 \cdot 7$ \\
\hline $\mathrm{C}_{19: 0}$ cyclo $\omega 8 \mathrm{c}$ & $15 \cdot 1$ & $3 \cdot 7 \pm 0 \cdot 7$ & $5 \cdot 5 \pm 3 \cdot 0$ & $3 \cdot 6$ & $1 \cdot 8$ & $2 \cdot 5 \pm 0 \cdot 7$ & $6 \cdot 3 \pm 0 \cdot 1$ & - \\
\hline Summed feature $2^{\star}$ & $11 \cdot 7$ & $7 \cdot 4 \pm 0 \cdot 9$ & $8 \cdot 2 \pm 2 \cdot 8$ & $8 \cdot 5$ & $5 \cdot 6$ & $8 \cdot 1 \pm 1 \cdot 1$ & $7 \cdot 3 \pm 0 \cdot 7$ & $5 \cdot 9$ \\
\hline Summed feature $3^{*}$ & $2 \cdot 3$ & $14 \cdot 5 \pm 1 \cdot 8$ & $9 \cdot 1 \pm 4 \cdot 9$ & $19 \cdot 1$ & $17 \cdot 6$ & $13 \cdot 6 \pm 1 \cdot 9$ & $12 \cdot 6 \pm 0 \cdot 1$ & $18 \cdot 2$ \\
\hline
\end{tabular}

*Summed features are groups of two or three fatty acids that cannot be separated by GLC with the MIDI system. Summed feature 2 comprises $\mathrm{C}_{14: 0} 3-\mathrm{OH}$, iso- $\mathrm{C}_{16: 1} \mathrm{I}$, an unidentified fatty acid with an equivalent chain length of 10.928 and $\mathrm{C}_{12: 0}$ ALDE, or any combination of these fatty acids. Summed feature 3 comprises $\mathrm{C}_{16: 1} \omega 7 c$ and/or iso- $\mathrm{C}_{15: 0} 2-\mathrm{OH}$.

\section{Acknowledgements}

This work was supported from the 2006 grant of KOSEF ('Functional study of saponin biosynthesis genes by metabolomics in Panax ginseng') and by a BK21 research fellowship from the Ministry of Education and Human Resource Development, Korea.

\section{References}

An, D. S., Im, W. T., Yang, H. C., Yang, D. C. \& Lee, S. T. (2005). Dyella ginsengisoli sp. nov., a $\beta$-glucosidase-producing bacterium. Int J Syst Evol Microbiol 55, 1625-1628.

Atlas, R. M. (1993). Handbook of Microbiological Media. Edited by L. C. Parks. Boca Raton, FL: CRC Press.

Ausubel, F. M., Brent, R., Kingston, R. E., Moore, D. D., Seidman, J. G., Smith, J. A. \& Struhl, K. (editors) (1995). Short Protocols in Molecular Biology: a Compendium of Methods from Current Protocols in Molecular Biology, 3rd edn. New York: Wiley.

Buck, J. D. (1982). Nonstaining (KOH) method for determination of Gram reactions of marine bacteria. Appl Environ Microbiol 44, 992-993.

Cappuccino, J. G. \& Sherman, N. (2002). Microbiology: a Laboratory Manual, 6th edn. Menlo Park, CA: Benjamin Cummings.

Coenye, T. \& Vandamme, P. (2003). Diversity and significance of Burkholderia species occupying diverse ecological niches. Environ Microbiol 5, 719-729.

Coenye, T., Laevens, S., Willems, A., Ohlen, M., Hannant, W., Govan, J. R. W., Falsen, E. \& Vandamme, P. (2001). Burkholderia fungorum sp. nov. and Burkholderia caledonica sp. nov., two new species isolated from the environment, animals and human clinical samples. Int J Syst Evol Microbiol 51, 1099-1107.

Coenye, T., Henry, D., Speert, D. P. \& Vandamme, P. (2004). Burkholderia phenoliruptrix sp. nov., to accommodate the 2,4, 5-trichlorophenoxyacetic acid and halophenol-degrading strain AC1100. Syst Appl Microbiol 27, 623-627.

Ezaki, T., Hashimoto, Y. \& Yabuuchi, E. (1989). Fluorometric deoxyribonucleic acid-deoxyribonucleic acid hybridization in microdilution wells as an alternative to membrane filter hybridization in which radioisotopes are used to determine genetic relatedness among bacterial strains. Int J Syst Bacteriol 39, 224-229.

Felsenstein, J. (1985). Confidence limits on phylogenies: an approach using the bootstrap. Evolution 39, 783-791.

Fitch, W. M. (1971). Toward defining the course of evolution: minimum change for a specific tree topology. Syst Zool 20, 406-416.

Goris, J., Dejonghe, W., Falsen, E., De Clerck, E., Geeraerts, B., Willems, A., Top, E. M., Vandamme, P. \& De Vos, P. (2002). Diversity of transconjugants that acquired plasmid pJP4 or pEMT1 after inoculation of a donor strain in the A- and B-horizon of an agricultural soil and description of Burkholderia hospita sp. nov. and Burkholderia terricola sp. nov. Syst Appl Microbiol 25, 340-352.

Goris, J., De Vos, P., Caballero-Mellado, J., Park, J., Falsen, E., Quensen, J. F., III, Tiedje, J. M. \& Vandamme, P. (2004). Classification of the biphenyl- and polychlorinated biphenyldegrading strain $\mathrm{LB}_{400}{ }^{\mathrm{T}}$ and relatives as Burkholderia xenovorans sp. nov. Int J Syst Evol Microbiol 54, 1677-1681.

Hall, T. A. (1999). BioEdit: a user-friendly biological sequence alignment editor and analysis program for Windows 95/98/NT. Nucleic Acids Symp Ser 41, 95-98.

Im, W.-T., Bae, H.-S., Yokota, A. \& Lee, S. T. (2004). Herbaspirillum chlorophenolicum sp. nov., a 4-chlorophenol-degrading bacterium. Int J Syst Evol Microbiol 54, 851-855.

Kim, M. K., Im, W.-T., Ohta, H., Lee, M. \& Lee, S.-T. (2005). Sphingopyxis granuli sp. nov., a $\beta$-glucosidase-producing bacterium in the family Sphingomonadaceae in the $\alpha-4$ subgroup of the Proteobacteria. J Microbiol 43, 111-116.

Kimura, M. (1983). The Neutral Theory of Molecular Evolution. Cambridge: Cambridge University Press. 
Komagata, K. \& Suzuki, K. (1987). Lipid and cell wall analysis in bacterial systematics. Methods Microbiol 19, 161-207.

Kouker, G. \& Jaeger, K.-E. (1987). Specific and sensitive plate assay for bacterial lipase. Appl Environ Microbiol 53, 211-213.

Kumar, S., Tamura, K. \& Nei, M. (2004). MEGA3: integrated software for molecular evolutionary genetics analysis and sequence alignment. Brief Bioinform 5, 150-163.

Mesbah, M., Premachandran, U. \& Whitman, W. B. (1989). Precise measurement of the $\mathrm{G}+\mathrm{C}$ content of deoxyribonucleic acid by highperformance liquid chromatography. Int J Syst Bacteriol 39, 159-167.

Poly, F., Monrozier, L. J. \& Bally, R. (2001). Improvement in the RFLP procedure for studying the diversity of nifH genes in communities of nitrogen fixers in soil. Res Microbiol 152, 95-103.

Saitou, N. \& Nei, M. (1987). The neighbor-joining method: a new method for reconstructing phylogenetic trees. Mol Biol Evol 4, 406-425.

Sasser, M. (1990). Identification of bacteria by gas chromatography of cellular fatty acids. MIDI Technical Note 101. Newark, DE: MIDI.
Sessitsch, A., Coenye, T., Sturz, A. V. \& 9 other authors (2005). Burkholderia phytofirmans sp. nov., a novel plant-associated bacterium with plant-beneficial properties. Int J Syst Evol Microbiol 55, 1187-1192.

Ten, L. N., Im, W.-T., Kim, M.-K., Kang, M.-S. \& Lee, S.-T. (2004). Development of a plate technique for screening of polysaccharidedegrading microorganisms by using a mixture of insoluble chromogenic substrates. J Microbiol Methods 56, 375-382.

Thompson, J. D., Gibson, T. J., Plewniak, F., Jeanmougin, F. \& Higgins, D. G. (1997). The CLUSTAL_X windows interface: flexible strategies for multiple sequence alignment aided by quality analysis tools. Nucleic Acids Res 25, 4876-4882.

Yabuuchi, E., Kosako, Y., Oyaizu, H., Yano, I., Hotta, H., Hashimoto, Y., Ezaki, T. \& Arakawa, M. (1992). Proposal of Burkholderia gen. nov. and transfer of seven species of the genus Pseudomonas homology group II to the new genus, with the type species Burkholderia cepacia (Palleroni and Holmes 1981) comb. nov. Microbiol Immunol 36, 1251-1275. 